\title{
Does insulin-like growth factor influence prognosis ten months after myocardial infarction?
}

\section{Insülin benzeri büyüme faktörü miyokard infarktüsünden on ay sonra prognozu etkiler mi?}

\author{
Yücel Yılmaz ${ }^{1 *}$ (D) , Mustafa Duran ${ }^{2}$ (D) , Mustafa Altay ${ }^{3}$ (D), Eyüp Özkan ${ }^{1}$ (D), Fatih Tanriverdi ${ }^{4}$ (D), \\ Namık Kemal Eryol ${ }^{5}$ \\ ${ }^{1}$ Kayseri Education and Research Hospital, Department of Cardiology, Kayseri, Turkey \\ ${ }^{2}$ Ankara Education and Research Hospital, Department of Cardiology, Ankara, Turkey \\ ${ }^{3}$ Ankara Keciören Education and Research Hospital, Department of Endocrinology and Metabolism, Ankara, Turkey \\ ${ }^{4}$ Erciyes University, Faculty of Medicine, Department of Endocrinology and Metabolism, Kayseri, Turkey \\ ${ }^{5}$ Erciyes University, Faculty of Medicine, Department of Cardiology, Kayseri, Turkey \\ * Corresponding author: Yücel Yilmaz E-mail: dryyilmaz@hotmail.com ORCID: 0000-0003-2340-027X \\ Received: 1 January 2019 Accepted: 14 May 2019
}

\begin{abstract}
Background: We investigated the levels of insulin-like growth factor-1 (IGF-1) in acute myocardial infarction (AMI) patients, and we determined whether a decrease in IGF-1 could influence long-term prognosis.

Methods: In total, 65 patients who were admitted to our hospital for AMI and 25 healthy controls were included in this study. Fasting blood samples were obtained from all patients immediately after AMI and 10 months later to determine their IGF-1 and insulin-like growth factor binding protein-3 (IGFBP-3) levels. Fasting blood samples were obtained from the control group. The patients were also evaluated for cardiac events 10 months after AMI.

Results: The IGF-1 levels were higher in the AMI patients than in the healthy controls $(p=0.002)$; after 10 months, both the IGFBP-3 and IGF-1 levels were higher. No differences were found in cardiac event occurrence between patients with low and high IGF-1 and IGFBP-3 levels (for both the baseline and 10-month values).

Conclusions: The serum total IGF-1 and IGFBP-3 levels were higher in the AMI patients compared to the control patients; however, there was no correlation between the IGF-1 and IGFBP-3 levels and cardiac events during the 10-month period after AMI. Additional studies are needed to clarify the time required for IGF-1 and IGFBP-3 level normalization after AMI, and to determine the effects of IGF-1 and IGFBP-3 on the long-term prognosis of patients after AMI.
\end{abstract}

Keywords: acute myocardial infarction, cardiac events, insulin-like growth factor-1

( 2020 by the authors; licensee MEDITAGEM Ltd., Turkey. This article is an open access article distributed under the terms and conditions of the Creative Commons Attribution License (http://creativecommons.org/licenses/by/4.0/). 


\section{öz}

Amaç: Akut miyokard infarktüslü (AMI) hastalarda insülin benzeri büyüme faktörü-1 (IGF-1) düzeylerini araştırdık ve IGF-1'de bir azalmanın uzun vadeli prognozu etkileyip etkilemeyeceğini belirlemeyi amaçladık.

Yöntemler: AMi nedeniyle hastanemize başvuran 65 hasta ve 25 sağlıklı kontrol birey çalışmaya dahil edildi. İGF-1 ve insülin benzeri büyüme faktörü bağlayıcı protein-3 (IGFBP-3) seviyelerini belirlemek için AMi' den sonra en erken zamanda ve 10 ay sonra tüm hastalardan ve kontrol grubundan kan örnekleri alındı. Hastalar AMi' den 10 ay sonra kardiyak olayları açısından değerlendirildi.

Bulgular: IGF-1 düzeyleri, AMI hastalarında sağlıklı kontrollerden daha yüksekti ( $p=0,002)$; 10 ay sonra, hem IGFBP-3 hem de IGF-1 seviyeleri daha yüksekti. Düşük ve yüksek IGF-1 ve IGFBP-3 düzeyleri olan hastalarda kardiyak olay oluşumunda anlamlı fark bulunmadı (hem başlangıç hem de 10 aylık değerler için).

Sonuç: Serum total IGF-1 ve IGFBP-3 düzeyleri, AMi hastalarında kontrol hastalarına göre daha yüksekti; ancak, IGF-1 ve iGFBP-3 seviyeleri ile AMi sonrası 10 aylık dönemde kardiyak olaylar arasında korelasyon bulunamadı. AMi sonrası IGF-1 ve IGFBP-3 düzey normalleşmesi için gereken süreyi netleştirmek ve AMi sonrası hastaların uzun dönem prognozu üzerindeki etkilerini belirlemek için ilave çalışmalara ihtiyaç vardır.

Anahtar kelimeler: akut miyokard infarktüsü, kardiyak olay, insülin benzeri büyüme faktörü-1

\section{INTRODUCTION}

Insulin-like growth factor-1 (IGF-1) plays a pivotal role in the regulation of cellular growth, proliferation, and differentiation, and in the inhibition of apoptosis and necrosis. It also contributes to tissue remodeling and energy metabolism [1]. IGF-1 is transported in the circulation by carrier proteins known as IGF binding proteins (IGFBPs).

Low IGF-1 and high IGFBP-3 levels are associated with increased cardiovascular risk [2,3]. Previous studies reported that serum IGF-1 was related to heart failure [4,5] and coronary artery disease (CAD) [3, 6], and in particular with myocardial infarction $[7,8]$. IGF-1 may play an important role after acute myocardial infarction (AMI) in the protection of myocardial function [9-11]. However, only one previous study examined IGF-1/IGFBP-3 levels and their relationship with long-term mortality in AMI patients. Therefore, this study investigated long-term IGF-1/IGFBP-3 levels and determined their effects on mortality.

\section{METHODS}

In total, 65 patients who were admitted to our hospital for AMI (mean age: 52 \pm 9 years; range: 31-75 years; 59 males) were included in this study. In addition, 25 patients (mean age: $52 \pm 8$ years; range: $40-73$ years; 21 males) without CAD that met the exclusion criteria were also enrolled as controls. The inclusion criteria were a diagnosis of AMI, which was established according to World Health Organization criteria
[12]. Sixty two patients were evaluated for cardiac events and laboratory parameters 10 months later again.

Patients with uncontrolled hypertension (systolic blood pressure [SBP] of $140 \mathrm{mmHg}$ and/or diastolic blood pressure [DBP] of $\geq 90 \mathrm{mmHg}$ based on their history), diabetes mellitus, acromegaly, history of CAD or heart failure, thyroid deficiency, hepatic dysfunction, Killip score of 3-4, aortic or mitral valve dysfunction, cardiomyopathy, history of acute pericarditis or myocarditis, acute or chronic renal failure, systemic infection, musculoskeletal disease, or cancer, and those who were on medications that would affect serum IGF-1/IGFBP-3 levels were excluded from the study. All patients were informed of the study details, and the study protocol was approved by a regional ethics committee.

\section{Study Protocol}

Fasting blood samples were obtained from all patients in the hospital and after about 10 months to establish their IGF-1 and IGFBP-3 levels. In the control group, fasting blood samples were obtained to measure their parameters.

\section{Laboratory Studies}

IGF-1 and IGFBP-3 levels were measured by immunoradiodynamic measurement in serum separated from whole blood. For measurement of the IGF-1 levels, a DSL-5600 ACTIVE IGF-1 with EXTRACTION (Diagnostic System Laboratories, Inc.', Webster, TX, USA) kit was used; for measurement of the IGFBP-3 levels, a DSL-6600 ACTIVE ${ }^{\circ}$ IGFBP-3 (Diagnostic System Laboratories, Inc. ${ }^{\circ}$ ) kit was used. 

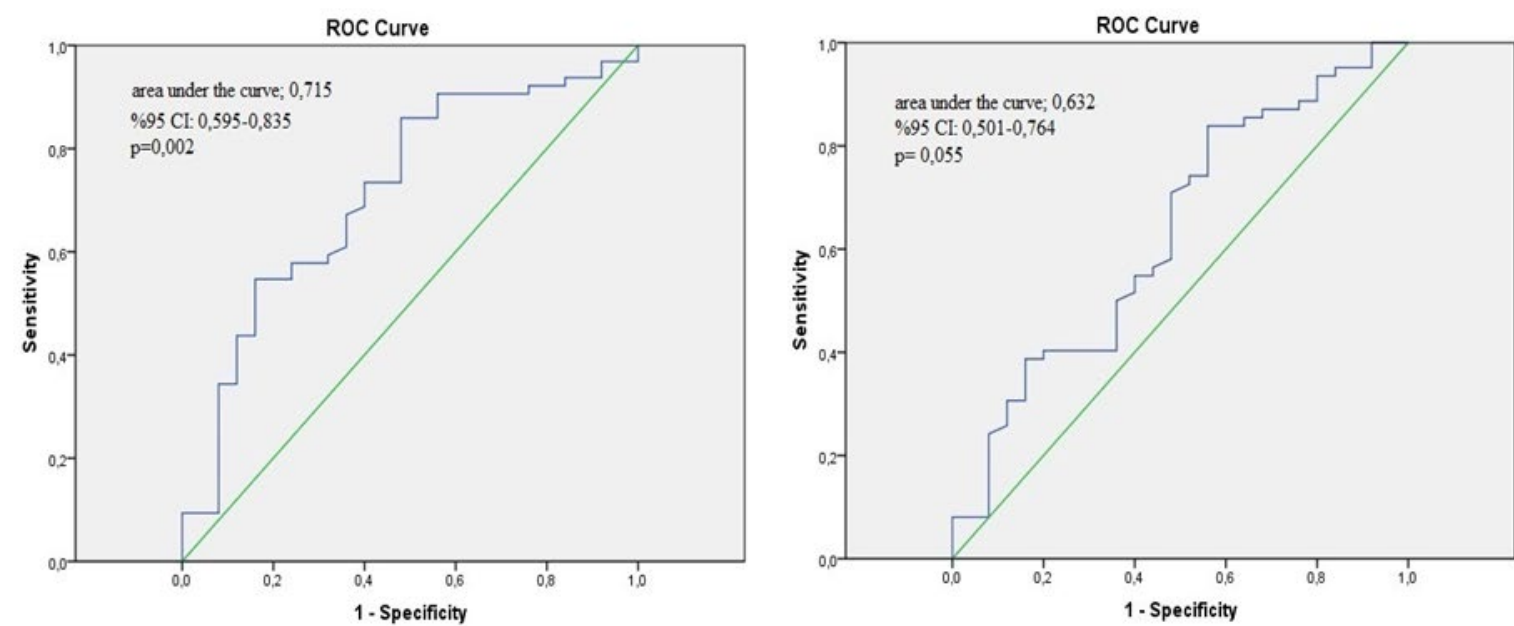

Figure 1. The receiver operating characteristic (ROC) curve of IGF-1 for baseline and $10^{\text {th }}$ month
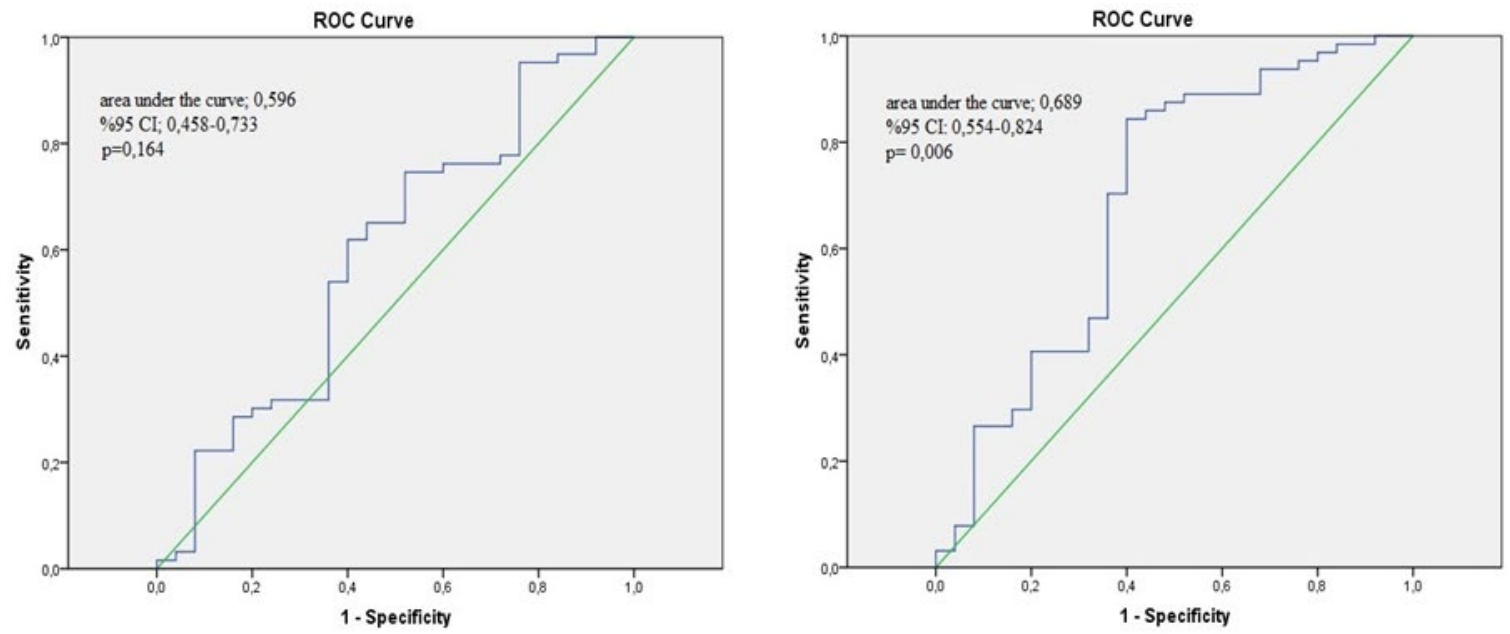

Figure 2. The receiver operating characteristic (ROC) curve of IGFBP-3 for baseline and $10^{\text {th }}$ month

\section{Statistical Analysis}

All analyses were performed using SPSS v16.0 for Windows. Quantitative variables were expressed as the mean value $\pm S D$ for parametric variables and as median or minimum-maximum levels for non-parametric variables. Comparisons of parametric values between the two groups were performed using the independent samples $t$-test. Comparisons of non-parametric values were performed using the Mann-Whitney $U$ test. Categorical variables were compared using the chi-squared test. The Pearson test was used to determine the correlation between parametric variables; the Spearman test was used for non-parametric variables. A two-tailed $p$-value $<0.05$ was considered statistically significant. A receiver operating characteristic (ROC) analysis was also performed; the best cut-off value, and the sensitivity and specificity at that point were determined (Figures 1 and 2).

\section{RESULTS}

In the AMI patients, the IGF-1 levels were higher whereas the SBP was lower compared with the control group $(p=0.002$ and 0.03 , respectively). All other parameters were similar between the two groups. After 10 months, the levels of IGFBP-3 remained significantly higher than in the control group; even though the IGF-1 levels tended to be higher, the values did not reach statistical significance $(p=0.006$ and 0.05, respectively) (Table 1). The 10-month IGF-1 and IGFBP3 levels were similar the baseline values ( $p>0.05)$.

The predictive value for serum IGF-1 levels (sensitivity of $64 \%$ and specificity of $67 \%$; area under the ROC curve $=0.715$ ) was $214 \mathrm{mg} / \mathrm{dl}$ at baseline and $156 \mathrm{mg} / \mathrm{dl}$ after 10 months (sensitivity of $52 \%$ and specificity of $71 \%$; area under the ROC curve=0.632) (Figure 1). The predictive value of serum IGFBP-3 levels (sensitivity of $56 \%$ and specificity of $65 \%$; area under the $\mathrm{ROC}$ curve $=0.596$ ) was $2738 \mathrm{mg} / \mathrm{dl}$ at baseline and $2836 \mathrm{mg} / \mathrm{dl}$ after 10 months (sensitivity of $60 \%$ 
Table 1. A comparison of the laboratory and epidemiological parameters between the patients with AMl and the control group at baseline and the $10^{\text {th }}$ month

\begin{tabular}{|c|c|c|c|c|c|c|}
\hline & \multicolumn{3}{|c|}{ Baseline } & \multicolumn{3}{c|}{$\mathbf{1}^{\text {th }}$ month } \\
\hline & Patients (n=65) & Controls (n=25) & $\mathbf{P}$ & Patients (n=62) & Controls (n=25) & P \\
\hline Age (years) & $52 \pm 9$ & $52 \pm 8$ & 0.5 & $53 \pm 8$ & $52 \pm 8$ & 0.6 \\
\hline HR/min & $71.5 \pm 9.5$ & $72.1 \pm 7.1$ & 0.4 & $68.8 \pm 10.5$ & $72.1 \pm 7.1$ & 0.05 \\
\hline SBP mmHg & $102.6 \pm 13$ & $109 \pm 10.9$ & 0.03 & $111.8 \pm 15.1$ & $109 \pm 10.9$ & 0.2 \\
\hline DBP mmHg & $55.2 \pm 9.1$ & $57.9 \pm 9.3$ & 0.2 & $61 \pm 11$ & $57.9 \pm 9.3$ & 0.1 \\
\hline HgA1c mg/dl & $5.7 \pm 0.5$ & $5.6 \pm 0.3$ & 0.2 & $5.9 \pm 0.7$ & $18.6 \pm 0.3$ & 0.05 \\
\hline TC mg/dl & $186.4 \pm 36.3$ & $185.4 \pm 37.8$ & 0.7 & $164.7 \pm 35.6$ & $185.4 \pm 37.8$ & 0.05 \\
\hline TG mg/dl & $147.3 \pm 124$ & $153.2 \pm 91.2$ & 0.2 & $150.6 \pm 81.2$ & $153.2 \pm 91.2$ & 0.8 \\
\hline HDL mg/dl & $47.5 \pm 12.8$ & $46.2 \pm 11.1$ & 0.9 & $42.2 \pm 12.1$ & $46.2 \pm 11.1$ & 0.06 \\
\hline LDL mg/dl & $109.6 \pm 30$ & $108.5 \pm 35.1$ & 0.5 & $92.4 \pm 29.3$ & $108.5 \pm 35.1$ & 0.06 \\
\hline IGF-1 & $243.6 \pm 82.4$ & $180.3 \pm 82$ & 0.002 & $219.6 \pm 87.2$ & $180.3 \pm 82$ & 0.05 \\
\hline IGFBP-3 & $3185.3 \pm 930.2$ & $2813.6 \pm 1071.3$ & 0.1 & $3501.3 \pm 760.4$ & $2813.6 \pm 1071.3$ & 0.006 \\
\hline
\end{tabular}

Abbreviations: AMI: acute myocardial infarction; IGF-1: insulin-like growth factor -1; IGFBP-3: IGF-binding protein-3; HR: heart rate; SBP: systolic blood pressure; DBP: diastolic blood pressure; HDL: high density lipoprotein; LDL: low density lipoprotein; TC: total cholesterol; TG: triglyceride; NS: not significant. A value of $p<0.05$ was considered to be statistically significant

Table 2. A comparison of cardiac events between the AMI patients with low or high IGF-1 and the IGFBP-3 levels at baseline and the $10^{\text {th }}$ month

\begin{tabular}{|c|c|c|c|}
\hline & & Complication (n) & $\mathbf{p}$ \\
\hline \multirow{2}{*}{ IGF-1 at baseline } & High & 7 & \multirow{2}{*}{0.782} \\
\hline & Low & 4 & \\
\hline \multirow{2}{*}{ IGF-1 at $10^{\text {th }}$ month } & High & 8 & \multirow{2}{*}{0.788} \\
\hline & Low & 2 & \\
\hline \multirow{2}{*}{ IGFBP-3 at baseline } & High & 6 & \multirow{2}{*}{0.281} \\
\hline & Low & 2 & \\
\hline \multirow{2}{*}{ IGFBP-3 at $10^{\text {th }}$ month } & High & 7 & \multirow{2}{*}{0.557} \\
\hline & Low & 2 & \\
\hline
\end{tabular}

Abbreviations: AMI: acute myocardial infarction; IGF-1: insulin-like growth factor-1; IGFBP-3: IGF- binding protein-3; NS: not significant. A value of $p<0.05$ was considered to be statistically significant

and specificity of $84 \%$; area under the ROC curve $=0.689$ )

(Figure 2). At the $10^{\text {th }}$ month, only 11 cardiac events were detected in 62 evaluated patients. No differences were found in the number of cardiac events between patients with low and high IGF-1 and IGFBP-3 levels (for both the baseline and 10-month values) (Table 2).

\section{DISCUSSION}

Several studies have suggested that low serum IGF-1 levels contribute to the pathogenesis of atherosclerosis [13-17]. Low serum IGF-1 and high IGFBP-3 levels were associated with an increased risk of CAD and mortality [2,3,11,18-20]. However, Kaplan et al. reported that low IGFBP-3 levels were significantly associated with an increased risk of coronary events. However, the same study found no association between IGF-1 levels and coronary event incidence [21].

A literature search revealed a limited number of studies investigating the relationship between serum IGF-1/IGFBP-3 levels and myocardial infarction, and the results of these studies were controversial. Investigators showed that the serum IGF-1 levels were low in patients with manifest CAD; however, this was not consistent in all studies [8, 22-26]. Sekuri et al. reported that the IGF-1 levels were significantly decreased only in ST segment elevation myocardial infarction (STEMI) patients, and that there was no difference in patients with unstable angina pectoris and non-ST segment elevation. There were no significant differences in IGFBP-3 levels between the two groups [27]. Yamagushi et al. reported that serum IGF-1 levels were decreased during the acute phase in patients with myocardial infarction [28]. However, the serum IGF-1 concentrations of the patients increased during the chronic phase (approximately 1 month later), similar to the IGF-1 concentrations in control subjects. However, Lee et al. reported that the total IGF-1 levels trended towards being higher $(p=0.17)$ and that the free IGF1 levels were significantly higher in patients with AMI [8]. In the present study, the serum total IGF-1 levels were significantly higher in patients with AMI compared to the healthy controls. The serum IGFBP-3 levels were also higher, but the values did not reach significance.

Previous studies showing that IGF-1 has beneficial effects on $C A D$ have suggested different underlying mechanisms. 
IGF-1 is important for tissue repair and cell proliferation; therefore, it may be involved in the pathogenesis of atherosclerosis. IGF-1 plays a critical role in cell cycle regulation and has mitogenic effects; additionally, it inhibits apoptosis and necrosis, which increases plaque stabilization [29,30]. In addition, IGF-1 facilitates neovascularization, increases nitric oxide production in the endothelium and muscle cells, and reduces cardiomyocyte loss post-AMI [31,32]. Thus, substantial evidence suggests a cardioprotective role for IGF-1. Growth hormone (GH) and insulin are major stimulating factors for IGF-1 secretion [33]. In this study, increased levels of GH and insulin may have sustained the increase in IGF-1.

The time required to return to normal IGF-1 levels and the association with long-term cardiac events are controversial. Sekuri et al. showed that serum IGF-1 levels were significantly increased after 3 months in the STEMI patient group, but did not reach the values in the control group [27]. Furthermore, no correlation was found between IGF-1 and IGFBP-3 levels and cardiac events during the 90-day followup period. Yamagushi et al. reported that the mean IGF-1 level on admission declined sharply and then promptly returned to baseline after 1 month, and that serum IGF-1 on admission was the most significant predictor of 90-day mortality in AMI patients [28]. Conti et al. found that low IGF1 levels were associated with 90-day cardiac events and appeared to return to the normal range after 1 year [1]. In our study, the IGF-1 levels decreased while the IGFBP-3 increased after 10 months, but neither value was significantly different from the baseline value $(p=0.5$ and 0.5 , respectively). After 10 months, both the IGF-1 and IGFBP-3 levels were statistically higher in the patient group than in the control group ( $p=0.05$ and 0.006 , respectively). In our study, no correlation between IGF-1 and IGFBP-3 levels and cardiac events was found during the 10-month follow-up period. Based on cross-sectional studies, we expected that the IGF-1 levels would be equal to or lower than those in the control group over time. Therefore, we hypothesize that to achieve the levels of IGF-1 found in cross-sectional studies, the follow-up period should be longer than 1 year.

Based on the mechanisms of IGF-1 and the studies mentioned above, we expected that the occurrence of cardiac events in patients with high IGF levels would be lower than in those with low levels of IGF-1 after 10 months. However, this was not the case. These results may be explained by the limitations of the current study. For example, the ejection fraction, rate of myocardial necrosis, performance index, and drugs used by the patients were not evaluated. Unfortunately, the design of our study did not allow us to perform a valid multivariate analysis. We were surprised by the finding that IGF-1 levels were not related to cardiac events. We believe that if the patients were followed for a longer period of time, we would obtain different results concerning the association between IGF-1, IGFBP-3, and cardiac events.

\section{CONCLUSIONS}

The serum total IGF-1 and IGFBP-3 levels were higher in AMI patients compared to the controls, but there was no correlation between IGF-1 and IGFBP-3 levels and cardiac events in the 10-month follow-up period after AMI. Additional studies are needed to clarify the levels of IGF-1 and IGFBP-3 and the time required to return to normal levels, and to clarify the long-term relationship between IGF1, IGFBP3, and cardiac events in patients with AMI.

\section{DECLARATION OF CONFLICT OF INTEREST}

The authors received no financial support for the research and/or authorship of this article. There is no conflict of interest.

\section{REFERENCES}

1. Conti E, Musumeci MB, De Giusti M, et al. IGF-1 and atherothrombosis: relevance to pathophysiology and therapy. Clin. Sci. (Lond). 2011; 120: 377-402.

2. Heald $A H$, Siddals $\mathrm{KW}$, Fraser $\mathrm{W}$, et al. Low circulating levels of insulin-like growth factor binding protein-1 (IGFBP-1) are closely associated with the presence of macrovascular disease and hypertension in type 2 diabetes. Diabetes. 2002; 51: 2629-2636.

3. Juul A, Scheike $T$, Davidsen, $M$, et al. Low serum insulinlike growth factor I is associated with increased risk of ischemic heart disease: a population-based casecontrol study. Circulation. 2002; 106: 939-944.

4. Vasan RS, Sullivan LM, D'Agostino RB, et al. Serum insulinlike growth factor I and risk for heart failure in elderly individuals without a previous myocardial infarction: The Framingham Heart Study. Ann Intern Med. 2003; 139: 642-648.

5. Bleumink GS, Rietveld I, Janssen JA, et al. Insulin-like growth factor-I gene polymorphism and risk of heart failure (the Rotterdam Study). Am J Cardiol. 2004; 94: 384-386. 
6. Van Bunderen CC, Oosterwerff MM, van Schoor NM, et al. Serum IGF1, metabolic syndrome, and incident cardiovascular disease in older people: a populationbased study. Eur J Endocrinol. 2013; 168: 393-401.

7. Friberg L, Werner S, Eggertsen $\mathrm{G}$ et al. Growth hormone and insulin-like growth factor- 1 in acute myocardial infarction. Eur Heart J. 2000; 21: 1547-1554.

8. Lee WL, Chen JW, Ting CT, et al. Wang, Changes of the insulin-like growth factor I system during acute myocardial infarction: implications on left ventricular remodeling. J Clin Endocrinol Metab. 1999: 84: 15751581.

9. Wang L, Ma W, Markovich R, et al. Chen, P.H. Wang, Regulation of cardiomyocyte apoptotic signaling by insulin-like growth factor I. Circ Res. 1998; 83: 516-522.

10. Li B, Setoguchi $M$, Wang $X$, et al. Insulin-like growth factor-1 attenuates the detrimental impact of nonocclusive coronary artery constriction on the heart. Circ Res. 1999; 84: 1007-1019.

11. Colao A. The GH-IGF-I axis and the cardiovascular system: clinical implications. Clinical Endocrinology. 2008; 69: 347-358.

12. Tunstall-Pedoe $H$, Kuulasmaa $K$, Amouyel $P$, et al. Myocardial infarction and coronary deaths in the World Health Organization MONICA Project: registration procedures, event rates, and case-fatality rates in 38 populations from 21 countries in four continents. Circulation. 1994; 90: 583-612.

13. Fagin JA. Induction of insulin-like growth factor I messenger RNA in rat aorta after balloon denudation. Circ Res. 1990; 66: 1755-1760.

14. Khorsandi MJ, Fagin JA, Giannella-Neto D, et al. Regulation of insulin-like growth factor-I and its receptor in rat aorta after balloon denudation: evidence for local bioactivity. J Clin Invest. 1992; 90: 1926-1931.

15. Schneider DJ, Sobel BE. Augmentation of synthesis of plasminogen activator inhibitor type 1 by insulin and insulin-like growth factor type I: implications for vascular disease in hyperinsulinemic states. Proc Natl Acad Sci USA. 1991; 88: 9959-9963.

16. Bennett MR, Evan Gl, Schwartz SM. Apoptosis of human vascular smooth muscle cells derived from normal vessels and coronary atherosclerotic plaques. J Clin Invest. 1995; 95: 2266-2274.
17. Higashi $Y$, Sukhanov $S$, Anwar $A$, et al. Aging, atherosclerosis, and IGF-1. J Gerontol A Biol Sci Med Sci. 2012; 67: 626-639.

18. Kaplan RC, Strickler HD, Rohan TE, et al. Insulin-Like Growth Factors and Coronary Heart Disease. Cardiol Rev. 2005; 13: 35-39.

19. Ruidavets JB, Luc G, Machez E, et al. Effects of insulin-like growth factor 1 in preventing acute coronary syndromes: The PRIME study. Atherosclerosis. 2011; 218: 464-469.

20. Laughlin GA, Barrett-Connor E, Criqui MH, et al. The prospective association of serum insulin-like growth factor I (IGF-I) and IGF-binding protein-1 levels with all cause and cardiovascular disease mortality in older adults: the Rancho Bernardo Study. J Clin Endocrinol Metab. 2004; 89: 114-120.

21. Kaplan RC, McGinn AP, Pollak MN, et al. Association of total insulin-like growth factor-I, insulin-like growth factor binding protein-1 (IGFBP-1), and IGFBP-3 levels with incident coronary events and ischemic stroke. J Clin Endocrinol Metab. 2007; 92: 1319-1325.

22. Spallarossa P, Brunelli C, Minuto F, et al. Insulin-like growth factor-I and angiographically documented coronary artery disease. Am J Cardiol. 1996; 77: 200-202.

23. Goodman-Gruen D, Barrett-Connor E, Rosen C. IGF-1 and ischemic heart disease in older people. J Am Geriatr Soc. 2000; 48: 860-861.

24. Janssen JA, Stolk RP, Pols HA, et al. Serum total IGF-I, free IGF-I, and IGFB-1 levels in an elderly population: relation to cardiovascular risk factors and disease. Arterioscler Thromb Vasc Biol. 1998; 18: 277-282.

25. Botker HE, Skjaerbaek C, Eriksen UH, et al. Insulin-like growth factor-I, insulin, and angina pectoris secondary to coronary atherosclerosis, vvasospasm, and syndrome $\mathrm{X}$. Am J Cardiol. 1997; 79: 961-963.

26. Heald AH, Cruickshank JK, Riste LK, et al. Close relation of fasting insulin-like growth factor binding protein-1 (IGFBP-1) with glucose tolerance and cardiovascular risk in two populations. Diabetologia. 2001; 44: 333-339.

27. Sekuri C, Arslan O, Utuk O, et al. Serum level of insulin-like growth factor- 1 and insulin-like growth factor binding protein-3 in acute coronary syndromes and relationship with prognosis. Anadolu Kardiyol Derg. 2004; 4: 209-212. 
28. Yamaguchi H, Komamura K, Choraku M, et al. Impact of serum insulin-like growth factor-1 on early prognosis in acute myocardial infarction. Intern Med. 2008; 47: 819825.

29. Le Roith D. Seminars in medicine of the Beth Israel Deaconess Medical Center. Insulin-like growth factors. N Engl J Med 1997; 336: 633-640.

30. Bornfeldt KE, Raines EW, Nakano T, et al. Insulin-like growth factor-I and platelet-derived growth factor-BB induce directed migration of human arterial smooth muscle cells via signaling pathways that are distinct from those of proliferation. J Clin Invest. 1994; 93: 1266-1274.
31. Muniyappa R, Walsh MF, Rangi JS, et al. Insulin like growth factor 1 increases vascular smooth muscle nitric oxide production. Life Sci. 1997; 61: 925-931.

32. Tsukahara H, Gordienko DV, Tonshoff B, et al. Direct demonstration of insulin-like growth factor-l-induced nitric oxide production by endothelial cells. Kidney Int. 1994; 45: 598-604.

33. Conti E, Andreotti F, Sciahbasi A, et al. Markedly reduced insulin-like growth factor-1 in the acute phase of myocardial infarction. J Am Coll. Cardiol. 2001; 38: 26-32. 